\title{
GLACIER RETREAT DIFFERENCES IN CHILEAN CENTRAL ANDES AND THEIR RELATION WITH ANTHROPOGENIC BLACK CARBON POLLUTION
}

\author{
F. Cereceda-Balic ${ }^{1,2^{*}}$, M.F. Ruggeri ${ }^{1}$, V.Vidal ${ }^{1,2}$ \\ ${ }^{1}$ Universidad Técnica Federico Santa María. Valparaíso, Chile. francisco.cereceda@usm.cl \\ ${ }^{2}$ Dept. of Chemistry. Universidad Técnica Federico Santa María. Valparaíso, Chile
}

KEY WORDS: Glacier Retreat, Black Carbon, Atmospheric Pollution, Landsat.

\begin{abstract}
:
Black Carbon (BC) is indicated as the main atmospheric pollutant that obscures snow surfaces and absorbs solar energy, which accelerates the melting of ice/snow and produces glacier retreat. The case of Chile is of particular interest because it has most part of the Andean cryosphere, which has responded strongly to climate change through a retreat of their glaciers, having implications in the availability of freshwater for the inhabitants and economic activities. In this work, the aim was to investigate and quantify for the first time the impact that $\mathrm{BC}$ could have on the differences observed in the glacial retreat in the study area, decoupling this impact of the climatic and glaciological factors, through which it has not been possible to explain the difference in glacier behavior in the zone. In this case, two glaciers with comparable characteristics from the Central Andes of Chile were studied: Olivares Alpha Glacier (OAG) and Bello Glacier (BG). The spatio-temporal evolution (2004-2014) was studied using remote sensing images (Landsat). This information was analyzed together with measured data of BC concentrations in air and snow for the year 2014. Results showed important differences in glacier retreat, $-27.6 \%$ for OAG vs. $-5.1 \%$ for BG (2004-2014), together with a significantly higher impact of BC in OAG than BG. Regarding the sources of the measured $\mathrm{BC}$, considering that both glaciers are at a similar distance from Santiago, it can be considered that there is another source influencing $\mathrm{OAG}$, which could be the mountain mining activities, considering the small distance existing between this glacier and the mines.
\end{abstract}

\section{INTRODUCTION}

Historically, atmospheric pollution produced by anthropogenic aerosols has received greater attention in urban areas, because these tend to present the highest levels of pollution, as well as concentrate most of the population exposed to health risks. However, in addition to the global effects on climate and health, these atmospheric aerosols can also cause local effects on remote ecosystems with equally important consequences. Such is the case of the cryosphere - the ecosystem in which water is found mostly in a solid-state, such as ice, snow or permafrost (Trombotto 2017). It has an essential importance for our life, playing a central role in the hydrological cycle and in the water supplies of surrounding populations. The aerosols generated by different sources are prone to be transported through the atmosphere to the ice, snow and glaciers, and are deposited on them. This deposition produces a darkening of the surfaces, decreasing the natural albedo, and consequently increasing the absorption of incident solar energy (Cereceda-Balic et al. 2018). In this way, the melting of ice/snow is accelerated, producing a glacier retreat due to the loss of mass.

Among the numerous substances that constitute these atmospheric aerosols, Black Carbon (BC), produced by incomplete combustion of fossil fuels and biomass, is indicated as the main compound that obscures snow surfaces and absorbs solar energy (Hadley and Kirchstetter 2012). Radiation transfer calculations indicate that seemingly small amounts of $\mathrm{BC}$ in snow (10-100 parts per billion) decrease their albedo by $1-5 \%$. When $\mathrm{BC}$ is included in climate models, the albedo reduction induced by it constitutes a positive radiative forcing that globally averaged is small $\left(0.05 \mathrm{~W} \mathrm{~m}^{-2}\right)$, but at regional level (calculated between 0.6 and $3.0 \mathrm{~W} \mathrm{~m}^{-2}$ ) is comparable to the disturbance caused by the accumulation of $\mathrm{CO}_{2}$ in the atmosphere since preindustrial times (Hadley and Kirchstetter 2012).

The case of Chile is of particular interest, taking into account that it has the largest portion of the Andean cryosphere: More than 90 glaciers $\left(116 \mathrm{~km}^{2}\right)$ in the northern zone; 1320 glaciers in the Central Andes $\left(900 \mathrm{~km}^{2}\right)$; about 300 glaciers in the southern zone $\left(400 \mathrm{~km}^{2}\right)$; and in Chilean Patagonia there are around of 20,000 $\mathrm{km}^{2}$ of ice cover, where Campos de Hielo Sur is the second largest mass of extrapolar ice in the world. Scientific evidence indicates that the Andes cryosphere has responded strongly to climate change through a retreat of these glaciers, which could have major implications for the availability of water resources in the short term (Molina et al. 2015), considering that these water reservoirs are the main source of freshwater for the inhabitants of Chile, as well as a vital resource for various economic activities, such as water plant treatment, agriculture, hydropower generation and mining. However, the potential impact of $\mathrm{BC}$ on glaciers, and especially in Chile, has only been explored very sparingly using direct measurements (Cereceda-Balic et al. 2012, 2018; Molina et al. 2015).

Specifically in the Chilean Central Andes, the glacial area variations have been relatively well-examined (Malmros et al. 2016; Farías-Barahona et al. 2019; Barcaza et al. 2017; Ayala et al. 2016; DGA 2010; Direccion General de Aguas 2011). All these works agreed that glaciers in this zone have retreated. However, none of these studies were exhaustive, with most including a restricted number of glaciers, covering different time intervals. Barcaza et al. (2017) presented a study about recent glacier variations in the Andes of Chile between 2003 and 2015. They highlighted that the largest recession rate in the Central Andes was observed at Olivares Alpha glacier, while other 
glaciers such as Cipreses, Cortaderal and Palomo showed small or no frontal changes. Malmros et al. (2016) also studied some glaciers from the Chilean Central Andes, but for a longer period of time (1955-2014). They also found that Olivares Alpha glacier has been the most affected in the zone, losing $63 \%$ of its ice area, while other glaciers, like Juncal Norte, have lost only $10 \%$ of it in the same period. Similar results were presented by Bown et al. (2008) and Pellicciotti et al. (2014). All works showed strong differences in the retreat of glaciers from the Central Andes, and they agreed that from the climatic and glaciological aspects, these differences could not be fully explained.

In this work, the main objective was to investigate and quantify for the first time the impact that air pollutants emitted by anthropogenic activities, especially $\mathrm{BC}$, could have on the differences observed in the glacial retreat in the study area, decoupling this impact of the climatic and glaciological factors, which as mentioned previously, they have already been studied and through which it has not been possible to clearly explain the difference in glacier behavior. In this case, two glaciers from the Central Andes of Chile were studied: Olivares Alfa Glacier and Bello Glacier. These two glaciers were selected because they have comparable characteristics in terms of location, area and altitude (Table 1). The spatio-temporal evolution of them was studied through the analysis of remote sensing images generated by Landsat satellites, using a semi-automated method to calculate their annual area variations in 10 years (2004-2014). This information was analyzed together with measured data of $\mathrm{BC}$ concentrations in air and snow from both glaciers for the year 2014.

\begin{tabular}{|c|c|c|}
\hline & $\begin{array}{c}\text { Olivares } \\
\text { Alpha } \\
\text { Glacier }\end{array}$ & $\begin{array}{c}\text { Bello } \\
\text { Glacier }\end{array}$ \\
\hline Calculated area year 2004 $\left(\mathrm{km}^{2}\right)$ & 5.1 & 3.8 \\
\hline Calculated area year 2014 $\left.\mathrm{km}^{2}\right)$ & 3.7 & 3.6 \\
\hline $\begin{array}{c}\text { Area change in 10 years 2004- } \\
\text { 2014 (km²) }\end{array}$ & -1.4 & -0.2 \\
\hline Max altitude (m.a.s.l) & 4900 & 4900 \\
\hline Distance from Santiago (km) & 50 & 65 \\
\hline $\begin{array}{c}\text { Distance from the nearest } \\
\text { mining area (km) }\end{array}$ & 7 & 50 \\
\hline Distance between glaciers $(\mathrm{km})$ & \multicolumn{2}{|c|}{45} \\
\hline
\end{tabular}

Table 1. Main characteristics of the selected glaciers

\section{MATERIALS AND METHODS}

\subsection{Description of the study area and the selected glaciers}

Two Andes glaciers located in the same climatic zone were selected for this study (Figure 1). First one was Olivares Alpha Glacier (OAG), a $3.7 \mathrm{~km}^{2}$ glacier located $50 \mathrm{~km}$ north-east Santiago (331 $11^{\prime} 37.67^{\prime \prime} \mathrm{S} ; 70^{\circ} 13^{\prime} 15.91^{\prime \prime} \mathrm{O}-4900$ m.a.s.l. OAG is placed within the Olivares basin, the most glaciated area of the Maipo River which has approximately $77 \mathrm{~km}^{2}$ of ice distributed among 148 glaciers (Stehlík et al. 2017). The basin has experienced a strong area shrinkage in recent decades, with about $25 \mathrm{~km}^{2}$ of the area lost since 1955 (Stehlík et al. 2017). OAG is located right next to two copper mountain open mining sites (Figure 2).

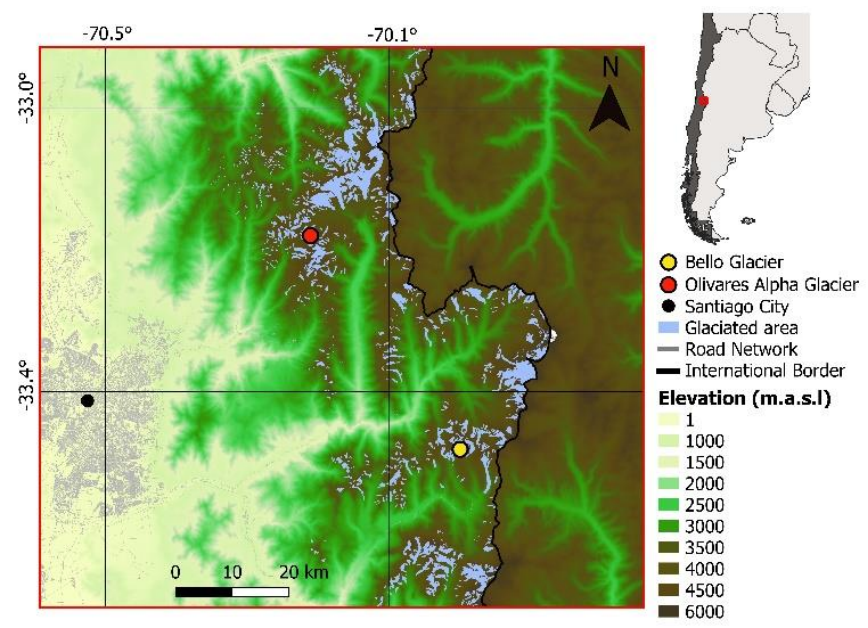

Figure 1. Study area and glaciers location

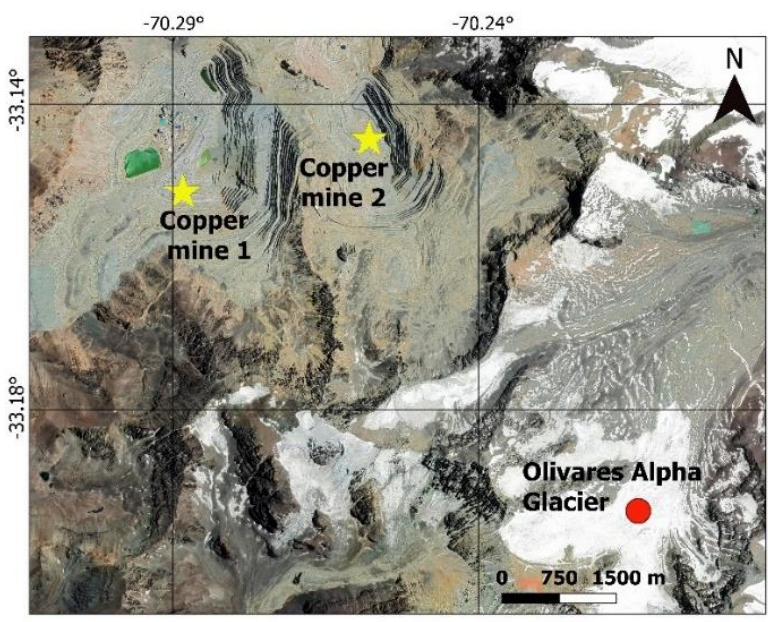

Figure 2. Location of Copper mining sites next to Olivares Alpha Glacier.

The second glacier selected for this study was Bello glacier (BG) (33³1'45.91"S; 6956'55.14"O, 4300 m.a.s.l), located around 65 $\mathrm{km}$ east from Santiago and $45 \mathrm{~km}$ south-east from OAG (Figure 1). $\mathrm{BG}$ is a $3.6 \mathrm{~km}^{2}$ glacier, part of Yeso River catchment among Yeso and Piramide glaciers in the semiarid Andes of central Chile (Burger et al. 2019). BG has not anthropogenic near activities like OAG.

Unlike the OAG, BG has been barely studied, and for the best knowledge of the authors, there are no other reports about its area changes over time, so this work would be the first to assess it.

\subsection{Analysis of remote sensing images}

Although it is well-known that the most accurate method for mapping glaciers from remote sensing data is manual delineation, this could be very time-consuming for a multitemporal change analysis (Burns and Nolin 2014). To reduce times, a very useful method is the semi-automated mapping of glaciers obtained by combining remote sensing data and GIS-based extraction (Man et al. 2014). Among the wide 
variety of satellite images available for this purpose, one of the most used are those generated by Landsat satellites (Zazulie et al. 2017; Man et al. 2014; Malmros et al. 2016; Burns and Nolin 2014), which provide different bands corresponding with different ranges of the electromagnetic spectrum (ES).

Landsat scenes (path 233, row 83) were downloaded from the United States Geological Survey (USGS), Earth Resources Observation and Science Center (EROS). They were orthorectified and projected to the Universal Transverse Mercator (UTM) coordinate system, zone 19 south.

The method used here is based on the fact that the reflectance of snow and debris-free glaciers is very high in the visible part of the ES $(0.4-0.7 \mu \mathrm{m})$ and it is nearly zero in the shortwave infrared portion of the ES $(1.5-1.8 \mu \mathrm{m})$. This difference in reflectance enables the semi-automated mapping (Burns and Nolin 2014).

In this case, the Normalized Difference Snow Index (NDSI) was used (Riggs, Hall, and Salomonson 1994), which has shown to be effective at distinguishing glacier ice from non-ice areas, especially where the ice is shadowed (Burns and Nolin 2014), a typical case in the Andes mountain. The NDSI was calculated from Landsat 5 Thematic Mapper (TM) using TM band 2 (visible green, $0.52-0.60 \mu \mathrm{m}$ ) and TM band 5 (mid-infrared, 1.55-1.75 $\mu \mathrm{m})$ as is shown in Equation (1):

$$
N D S I=\frac{T M 2-T M 5}{T M 2+T M 5}
$$

For the years 2013 and 2014, Landsat 8 Thermal Infrared Sensor (OLI-TIRS) images were used. In these cases, because Landsat 8 has a different spectral width for equivalent bands, the visible band corresponded with band 3 instead of band 2, and infrared band corresponded with band 6 instead of band 5 in the calculation of the NDSI using Equation (1). It was not possible to calculate the area for 2012 since there were no images available that meet the requirements on that date. Landsat images used in the present study are listed in Table 2 .

The main disadvantage of using the NDSI over other band calculations, is that it does not allow to differentiate snow from exposed glacier ice (Man et al. 2014). For this reason, the used images were carefully selected, considering only austral summer periods (December-march), when seasonal snow cover is at a minimum (Malmros et al. 2016). Additionally, images were subjected to visual inspection before being used, to verify the absence of snow as well as cloudiness in the areas of interest.

After calculating the NDSI, monoband images were obtained. A threshold value was applied to each image, above which a pixel was considered to be glacial ice, and below which it was not (Riggs, Hall, and Salomonson 1994). This threshold value was set from the analysis of each image obtained, and was usually around 0.6.

The calculations made on the images as well as the mapping and calculation of the areas for the analyzed years were carried out using the open source software QGIS v3.4.10

\subsection{Atmospheric BC monitoring}

Atmospheric BC concentration from Olivares Alpha and Bello glaciers, was determinate every 1 minute during 7 days in a row using a microAeth ${ }^{\circledR}$ Model AE51 (Aethlabs, CA, USA). The measurement principle is rate of change attenuation $(\lambda: 880 \mathrm{~nm})$ of transmitted light due to continuous collection of aerosol deposit on teflon-coated borosilicate glass fiber filter. Optical transmission through the 'Sensing' spot is measured by a stabilized LED light source and photo diode detector. The absorbance ("Attenuation, ATN") of the spot is measured relative to an adjacent "Reference" portion of the filter once per time-base period. The gradual accumulation of opticallyabsorbing particles leads to a gradual increase in ATN from one period to the next. The measurement at $880 \mathrm{~nm}$ is interpreted as concentration of $\mathrm{BC}$. The sample flow was $150 \mathrm{~mL} \mathrm{~min}^{-1}$.

\subsection{Snow sampling}

The snow samples were collected in both selected glaciers at early spring season 2014 (October - November), when the snowpack reaches its maximum depth before the onset of spring snowmelt (Cereceda-Balic et al. 2019). Snow samples consisted of a 5-cm thick layer collected from the top of the $1 \mathrm{~m}^{2}$ snowpack surface. Sample sizes were around 1000-1500 g and snow samples were kept frozen $\left(-20^{\circ} \mathrm{C}\right)$ until they could be processed. A plastic shovel was used to put snow into Whirl-Pak (Nasco) plastics bags. Clean dust-free, disposable gloves were used during sampling. All sampling material, included plastics bags, were washed first with Extran phosphate free detergent (Merck, Darmstadt, Germany) and then additionally with distilled water, followed by deionized water, and finally with HPLC ultrapure quality water obtained from a Milli-Q system (Merck, Darmstadt, Germany).

\subsection{BC concentration in snow}

Black Carbon concentration in snow samples from Olivares Alpha an Bello glaciers was determined by using a novel methodology developed recently by Cereceda and collaborators (2019). Methodology consists in a filter-based absorption method where snow samples are microwave-assisted melted, then filtered through an especially design filtration system able to generate a uniform $\mathrm{BC}$ spot on Nuclepore $47 \mathrm{~mm}$ polycarbonate filters. $\mathrm{BC}$ deposited in filters was analyzed using a SootScan ${ }^{\mathrm{TM}}$, Model OT21 Optical Transmissometer (Magee Scientific; Berkeley, CA, USA) were optical transmission was compared between the sample and reference filters at a wavelength of $880 \mathrm{~nm}$ for the measurement of BC mass concentrations, which were calculated using a 5 points calibration curve, previously prepared using diesel BC soot as standard (Cereceda-Balic et al. 2019). 


\section{RESULTS AND DISCUSSION}

\subsection{Glaciers area variations in the 2004-2014 period}

The resulting outlines from the image analysis of the two studied glaciers are shown in Figure 3, and details are presented in Table 2. Results showed important differences in the area changes between OAG y BG. OAG showed a marked decrease in its total area, resulting in a loss of $1.45 \mathrm{~km}^{2}$ between 2004 and 2014 , corresponding to $27.6 \%$ of its total area in 2004 . In contrast, BG presented little variation and a reduction of only $0.2 \mathrm{~km}^{2}$ between 2004 and 2014, which means a 5.1\% loss.

The area change rate has not been uniform throughout the period, with years for which there was evidence of growth in the glacial area. In 2006 both glacier experimented an area growth, which could be related with higher precipitations amount during the 2005 austral winter (Zazulie et al. 2017), which make sense considering that the increase in glacier mass in this geographical region is mainly due to snowfall accumulation. For other years (2010, 2011 and 2014) both glaciers showed a decrease in their area, being 2010 the year in which this loss was more severe for both. In 2007, 2008 and 2013, the BG showed an increase in its area, while the OAG showed decreases. It should be noted that in none of the analyzed years was an opposite trend, that is, growth for the OAG and loss for the BG.
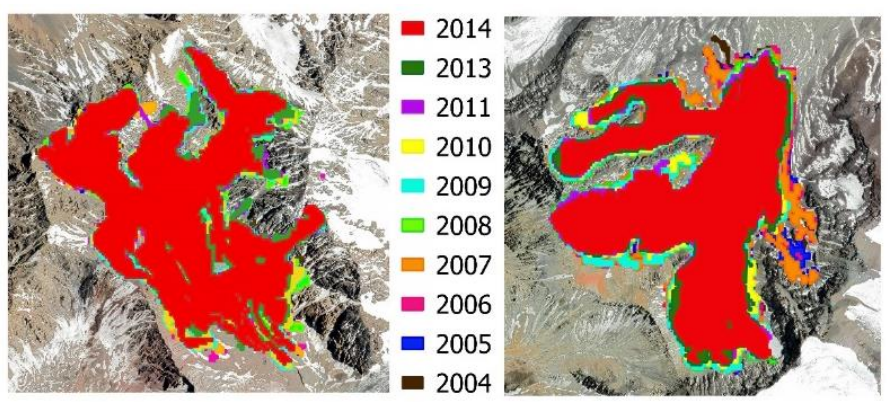

Figure 3. Mapped snow cover area for Bello glacier (left) and Olivares Alpha glacier (right)

\begin{tabular}{|c|c|c|c|c|c|}
\hline \multirow{2}{*}{ Year } & \multicolumn{2}{|c|}{ Calculated Area $\left(\mathrm{km}^{2}\right)$} & \multicolumn{2}{|c|}{ Annual area variation $\left(\mathrm{km}^{2} / \%\right)$} & \multirow{2}{*}{ Landsat image } \\
\hline & $\mathrm{OAG}$ & $\mathrm{BG}$ & $\mathrm{OAG}$ & BG & \\
\hline 2004 & 5.25 & 3.9 & & & $\begin{array}{r}\text { LT05_L1TP_233083_20040302_20161 } \\
202 \_01 \text { T1 2004-03-02 }\end{array}$ \\
\hline 2005 & 5.13 & 3.8 & $-0.12 /-2.3$ & $-0.1 /-2.6$ & $\begin{array}{r}\text { LT05_L1TP_233083_20050125_20161 } \\
12701 \text { T1 2005-01-25 }\end{array}$ \\
\hline 2006 & 5.3 & 4.1 & $0.17 / 3.3$ & $0.3 / 7.9$ & $\begin{array}{r}\text { LT05_L1TP_233083_20060220_20161 } \\
12301 \text { T1 2006-02-20 }\end{array}$ \\
\hline 2007 & 5.3 & 4.2 & $0 / 0$ & $0.1 / 2.4$ & $\begin{array}{r}\text { LT05_L1TP_233083_20070207_20161 } \\
11701 \text { T1 2007-02-07 }\end{array}$ \\
\hline 2008 & 4.9 & 4.2 & $-0.4 /-7.6$ & $0 / 0$ & $\begin{array}{r}\text { LT05_L1TP_233083_20080210_20161 } \\
10101 \text { T1 2008-02-10 }\end{array}$ \\
\hline 2009 & 4.9 & 4.2 & $0 / 0$ & $0 / 0$ & $\begin{array}{r}\text { LT05_L1TP_233083_20090212_20161 } \\
02701 \text { T1 2009-02-12 }\end{array}$ \\
\hline 2010 & 4.4 & 3.8 & $-0.5 /-10.2$ & $-0.4 /-9.5$ & $\begin{array}{r}\text { LT05_L1TP_233083_20100215_20161 } \\
016 \_01 \text { T1 2010-02-15 }\end{array}$ \\
\hline 2011 & 4.2 & 3.7 & $-0.2 /-4.6$ & $-0.1 /-2.6$ & $\begin{array}{r}\text { LT05_L1TP_233083_20110202_20161 } \\
010 \_01 \mathrm{~T} 12011-02-02\end{array}$ \\
\hline 2013 & 4 & 3.8 & $-0.2 /-4.8$ & $0.1 / 2.7$ & $\begin{array}{r}\text { LC08_L1TP_233083_20130412_20170 } \\
50501 \quad \mathrm{~T} 1 \quad 2013-04-12\end{array}$ \\
\hline 2014 & 3.8 & 3.6 & $-0.2 /-5.0$ & $-0.2 /-5.26$ & $\begin{array}{r}\text { LC08_L1TP_233083_20140125_20170 } \\
426 \_01 \_\mathrm{T} 1 \_2014-01-25\end{array}$ \\
\hline TOTAL & & & $-1.45 /-27.6$ & $-0.2 /-5.1$ & \\
\hline
\end{tabular}

Table 2. Calculated areas $\left(\mathrm{km}^{2}\right)$ and annual area variations $\left(\mathrm{km}^{2} / \%\right)$ for the studied glaciers. Right column lists the used Landsat images in each case.

\subsection{Atmospheric BC}

Concentrations of measured atmospheric $\mathrm{BC}$ showed average values of $108 \mathrm{ng} \mathrm{m}^{-3}$ in BG $294 \mathrm{ng} \mathrm{m}^{-3}$ in OAG. Figure 4 shows that atmospheric $\mathrm{BC}$ concentration in OAG presented a daily cycle during the first five sampling days (from 21 to 26 of October), increasing between 12 and $20 \mathrm{hrs}$. During these days, air temperature showed a similar daily cycle, with maximum values also reached during daylight hours. This potential correlation between air temperature and $\mathrm{BC}$ atmospheric levels in OAG may be due to the fact that, when temperature increases, the height of the boundary layer also does it, producing that pollutants generated by the nearby sources can reach greater height in the atmosphere and be transported to the surface of the $\mathrm{OAG}$, crossing the slopes and overcoming the physical barriers they entail. From day 6 (October 27), BC concentration decreased. The same profile could be seen in air temperature, reinforcing the hypothesis raised previously. Also, during the last sampling days, wind speed was higher and wind direction was less variable and came mainly from S and SW $\left(140^{\circ}-260^{\circ}\right)$, where Santiago City is located, suggesting that high levels of BC did not come from this source. In Figure 4 can be seen that in $\mathrm{BG}$, daily cycles of $\mathrm{BC}$ concentration and air temperature were 
not so clear. In BG, winds came mainly from southern directions $\left(100^{\circ}\right.$ to $\left.200^{\circ}\right)$, where no emissions source are located, which could help to levels of atmospheric BC were lower than in OAG.

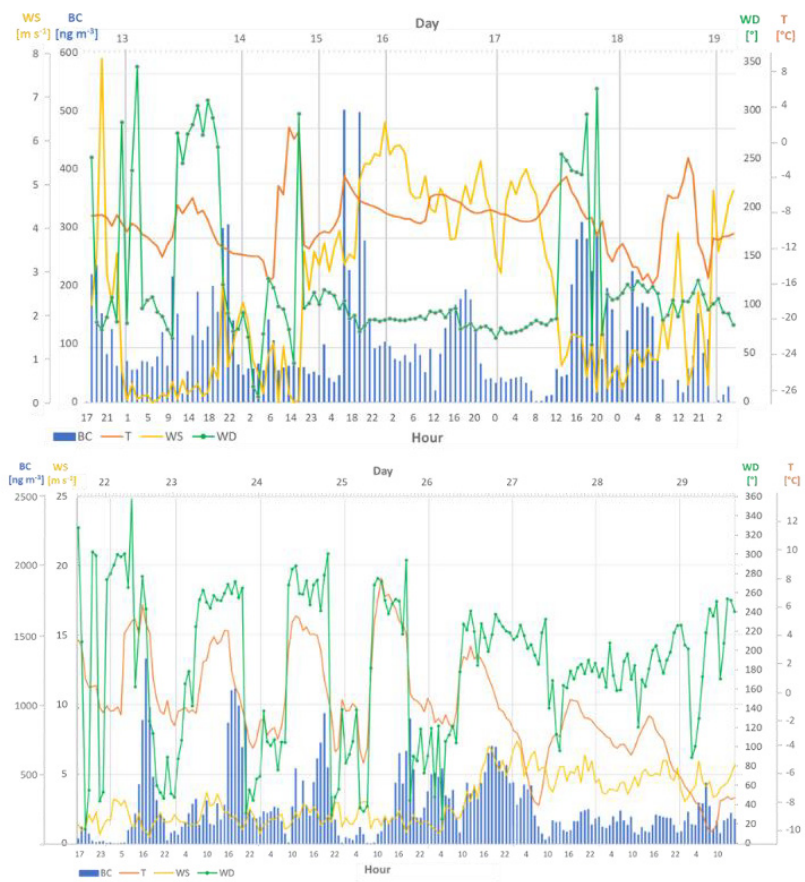

Figure 4. BC atmospheric concentration (blue bars, in $\mathrm{ng} \mathrm{m}^{-3}$ ), air temperature (orange line, ${ }^{\circ} \mathrm{C}$ ), wind speed (yellow line, $\mathrm{m} \mathrm{s}$ ${ }^{1}$ ) and wind direction (green line, deg) measured in BG (up) and OAG (down) during the monitoring period.

To establish whether the differences observed in $\mathrm{BC}$ atmospheric concentrations in $\mathrm{OAG}$ and $\mathrm{BG}$ are significant, the values observed in both glaciers were subjected to statistical nonparametrical tests of Kolmogorov-Smirnov (Figure 5). According to the statistical tests performed, the concentration of $\mathrm{BC}$ observed in the OAG is significantly different and higher than that observed in the BG. Considering that both glaciers are at similar distance from Santiago, it can be consider another source is significantly influencing OAG, which can be the mountain mining activities (Diesel Machinery) located close to it (Figure 2).

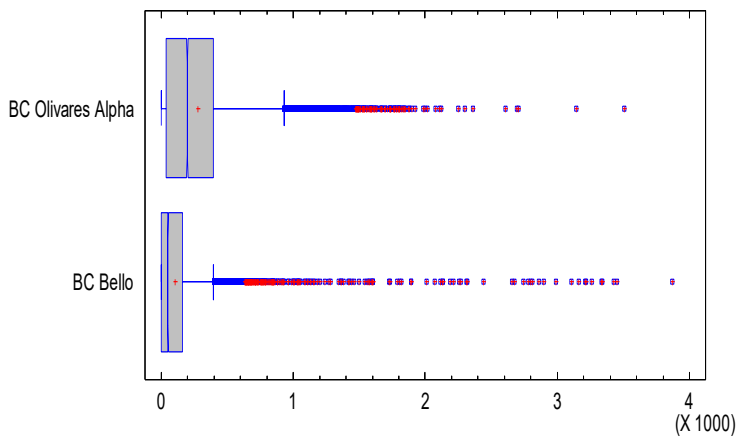

Figure 6. Box and whiskers plot for Black Carbon atmospheric concentration in Olivares Alpha and Bello glaciers.

\subsection{BC concentration in snow}

BC deposited in surface snow was determined in 3 samples taken in different points of each glacier. Results indicated that $\mathrm{BC}$ concentrations in OAG was 60 times higher than those found in BG (figure 7). These results are in concordance with the results obtained for atmospheric $\mathrm{BC}$ concentrations, indicating higher impact of this pollutant over OAG.

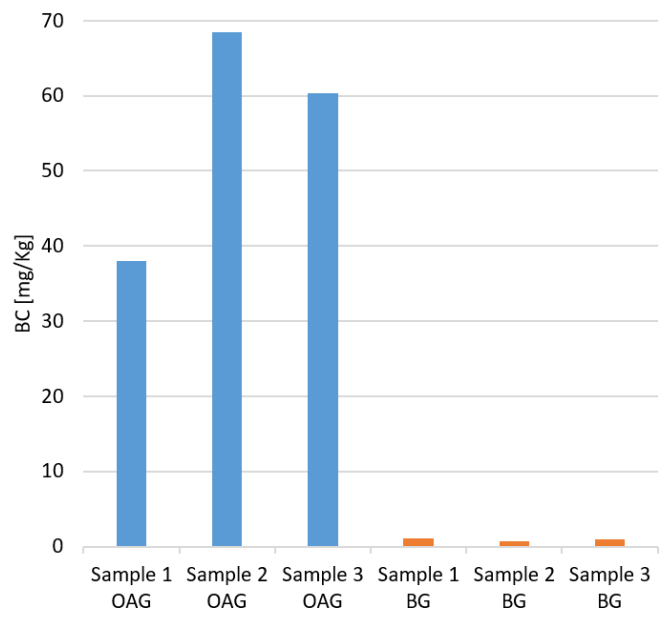

Figure 7. $\mathrm{BC}$ concentration in snow samples obtained in $\mathrm{OAG}$ and BG.

\section{CONCLUSIONS}

This work presented novel evidence of the existent link between the air pollutants emitted by anthropogenic activities, especially $\mathrm{BC}$, and the differences observed in the glacial retreat in the Chilean Central Andes. Here, the impact of the climatic and glaciological factors, which have already been studied and through which it has not been possible to clearly explain the difference in glacier behavior has been decoupled from the atmospheric pollution effect, since OAG and BG belong to the same basin, they have similar characteristics in terms of location, area and altitude but they have a very different behavior related to area changes over time. The differences in glacier retreat, $27.6 \%$ for OAG vs. $-5.1 \%$ for BG between 2004 and 2014, could be explained by the fact that OAG presented a significantly higher impact of $\mathrm{BC}$ than $\mathrm{BG}$, which resulted in lower albedo and consequently, a higher retreat rate. Regarding the sources of the measured $\mathrm{BC}$ in each case, considering that both glaciers are at similar distance from Santiago, it can be consider that there is other source significantly influencing OAG, which could be the mountain mining activities (Diesel Machinery), taking into account the small distance existing between this glacier and the mines (Figure 2).

\section{ACKNOWLEDGEMENTS}

The authors thank to Fondef Project D19I10359 and Fondecyt Postdoctoral Project $n^{\circ} 3190513$ for financial support. The authors acknowledge United States Geological Survey (USGS) for the satellite imagery from Landsat 5 and Landsta 8. Landsat imagery is available at https://earthexplorer.usgs.gov/ 


\section{REFERENCES}

Ayala, A., F. Pellicciotti, S. MacDonell, J. McPhee, S. Vivero, C. Campos, and P. Egli. 2016. "Modelling the Hydrological Response of Debris-Free and DebrisCovered Glaciers to Present Climatic Conditions in the Semiarid Andes of Central Chile." Hydrological $\begin{array}{llll}\text { Processes } & 30 & \text { (22): } & 4036-58 .\end{array}$ https://doi.org/10.1002/hyp.10971.

Barcaza, Gonzalo, Samuel U. Nussbaumer, Guillermo Tapia, Javier Valdés, Juan Luis García, Yohan Videla, Amapola Albornoz, and Víctor Arias. 2017. "Glacier Inventory and Recent Glacier Variations in the Andes of Chile, South America." Annals of Glaciology 58 (75): 166-80. https://doi.org/10.1017/aog.2017.28.

Bown, Francisca, Andrés Rivera, and César Acuña. 2008. "Recent Glacier Variations at the Aconcagua Basin, Central Chilean Andes." Annals of Glaciology 48: 43-48. https://doi.org/10.3189/172756408784700572.

Burger, Flavia, Alvaro Ayala, David Farias, Thomas E. Shaw, Shelley MacDonell, Ben Brock, James McPhee, and Francesca Pellicciotti. 2019. "Interannual Variability in Glacier Contribution to Runoff from a High-Elevation Andean Catchment: Understanding the Role of Debris Cover in Glacier Hydrology." Hydrological Processes 33 (2): 214-29. https://doi.org/10.1002/hyp.13354.

Burns, Patrick, and Anne Nolin. 2014. "Using AtmosphericallyCorrected Landsat Imagery to Measure Glacier Area Change in the Cordillera Blanca, Peru from 1987 to 2010." Remote Sensing of Environment 140. Elsevier B.V.: 165-78. https://doi.org/10.1016/j.rse.2013.08.026.

Cereceda-Balic, Francisco, Tamara Gorena, Camila Soto, Victor Vidal, Magín Lapuerta, and Hans Moosmüller. 2019. "Optical Determination of Black Carbon Mass Concentrations in Snow Samples: A New Analytical Method." Science of The Total Environment 697. Elsevier B.V.: 133934. https://doi.org/10.1016/j.scitotenv.2019.133934.

Cereceda-Balic, Francisco, M R Palomo-marín, E Bernalte, V Vidal, J Christie, X Fadic, J L Guevara, C Miro, and E Pinilla Gil. 2012. "Impact of Santiago de Chile Urban Atmospheric Pollution on Anthropogenic Trace Elements Enrichment in Snow Precipitation at Cerro Colorado , Central Andes." Atmospheric Environment 47. Elsevier Ltd: $51-57$. https://doi.org/10.1016/j.atmosenv.2011.11.045.

Cereceda-Balic, Francisco, Víctor Vidal, Hans Moosmüller, and Magín Lapuerta. 2018. "Reduction of Snow Albedo from Vehicle Emissions at Portillo, Chile." Cold Regions Science and Technology 146 (May 2017). Elsevier: 4352. https://doi.org/10.1016/j.coldregions.2017.11.008.

DGA. 2010. "Balance de Masa En El Glaciar Echaurren Norte Temporadas 1997-1998 a 2008-2009.” Dirección General de Aguas, 32

Direccion General de Aguas. 2011. "Variaciones Recientes de Glaciares En Chile, Según Principales Zonas
Glaciológicas. Informe Final.”

Farías-Barahona, David, Sebastián Vivero, Gino Casassa, Marius Schaefer, Flavia Burger, Thorsten Seehaus, Pablo Iribarren-Anacona, Fernando Escobar, and Matthias H. Braun. 2019. "Geodetic Mass Balances and Area Changes of Echaurren Norte Glacier (Central Andes, Chile) between 1955 and 2015." Remote Sensing 11 (3) https://doi.org/10.3390/rs11030260.

Hadley, Odelle L., and Thomas W. Kirchstetter. 2012. "BlackCarbon Reduction of Snow Albedo." Nature Climate Change 2 (6). Nature Publishing Group: 437-40. https://doi.org/10.1038/nclimate1433.

Malmros, Jeppe K., Sebastian H. Mernild, Ryan Wilson, Jacob C. Yde, and Rasmus Fensholt. 2016. "Glacier Area Changes in the Central Chilean and Argentinean Andes 1955-2013/14.” Journal of Glaciology 62 (232): 391-401. https://doi.org/10.1017/jog.2016.43.

Man, Q. X., H. D. Guo, G. Liu, and P. L. Dong. 2014. "Comparison of Different Methods for Monitoring Glacier Changes Observed by Landsat Images." IOP Conference Series: Earth and Environmental Science 17 (1): 1-6. https://doi.org/10.1088/1755-1315/17/1/012127.

Molina, Luisa T, Laura Gallardo, M Andrade, D Baumgardner, and R Bórquez. 2015. "Pollution and Its Impacts on the South American Cryosphere Earth' S Future." Earth's Future 3: 345-69. https://doi.org/10.1002/2015EF000311.Universitario.

Pellicciotti, F., S. Ragettli, M. Carenzo, and J. McPhee. 2014. "Changes of Glaciers in the Andes of Chile and Priorities for Future Work." Science of the Total Environment 493. Elsevier B.V.: https://doi.org/10.1016/j.scitotenv.2013.10.055.

Riggs, George, Dorothy Hall, and Vincent Salomonson. 1994. "A Snow Index for the Landsat Thematic Mapper and Moderate Resolution Imaging Spectroradiometer." In Proceedings of IGARSS 1994: IEEE International Geoscience and Remote Sensing Symposium, 11:1942-44. Pasadena, California https://doi.org/10.1109/IGARSS.1994.399618.

Stehlík, M., P. Hermann, S. Torres, J. Kiselák, and A. Rivera. 2017. "On Dynamics Underlying Variance of Mass Balance Estimation in Chilean Glaciers." Ecological Complexity 31: 149-64. https://doi.org/10.1016/j.ecocom.2017.06.008.

Trombotto, Darío. 2017. “Definición de Criosfera.” Enciclopedia Web Cricyt. 2017. http://www.cricyt.edu.ar/enciclopedia/terminos/Criosfera .htm.

Zazulie, Natalia, Elodie Briche, Graciela B. Raga, and Matilde Rusticucci. 2017. "Spatio-Temporal Mapping of Glacier Fluctuations in the Subtropical Central Andes: Case Studies of Alto Del Plomo and Volcan Maipo.” Remote Sensing Applications: Society and Environment 8. $\begin{array}{lll}\text { Elsevier } & \text { B.V.: } & 140-47 .\end{array}$ https://doi.org/10.1016/j.rsase.2017.08.009. 